\title{
The Determinants of Moroccan Firm's Financial Structure
}

\author{
By Brahim Bouayad* \\ Salah Eddine Kartobi ${ }^{\dagger}$
}

\begin{abstract}
The aim of our paper is to try to determine financial structure of firms using a financing convention theory. Our research focused on a panel of listed 50 non-financial firms of Casablanca Stock Exchange. We apply a principal components analysis to identify more appropriate factors that determine funding regimes choice. We then use hierarchical cluster analysis to classify these listed non-financial firms by cluster. Our results show that financial structure is influenced by the nature of needs for funding. We find three separate funding regimes over the period 2003-2010: (i) autonomy regime, (ii) debt regime and (iii) overdraft regime. On the basis of these findings, the study concludes that the first perform reasonably well in predicting financial performance. The second in predicting investment while the third, in predicting the importance of financing need of transactions.
\end{abstract}

Keywords: Firm's financial structure, Funding regimes, Moroccan non-financial firms, Pecking Order and Market Timing Theories, Tradeoff.

\section{Introduction}

The question to determine the choice between projects financing in the prior research on firms' financing discusses, among others topics, self-financing, debt or equity. The balance between all these choices allows the firm to optimize its overall value by focusing on a trade-off to use for financing. Modigliani and Miller (1958) were the first to give a genuine reflection on corporate financing choices. They showed ${ }^{2}$ that the value of a firm is independent of its financial structure. Only the firms' ability to generate cash flows determines its value.

The lack of realism of the Modigliani and Miller's model has led to the emergence of many new financing theories that have apprehended the determinants of the financial structure, such as the Tradeoff (Kraus and Litzenberger 1973, Frank and Goyal 2011), Pecking Order (Donaldson ${ }^{3}$ 1961, Stewart Myers and Majluf 1984) and the Market Timing (Baker and Wurgler 2002) Theories.

The purpose of the first theory is to find the optimal mix of market versus nonmarket debt and specification of priority. Then, a balance between the

\footnotetext{
*Director of GREER, (Laboratory for Research in, Energy Economics, Environment and Resources), Cadi Ayyad University, Morocco.

†Professor, Member of GREER, Faculty of Economics and Law, Cadi Ayyad University, Marrakesh, Morocco.

${ }^{2}$ Their analysis was based on the following assumptions: perfect markets, lack of information asymmetries and conflicts of interest among economic agents, no-existence of bankruptcy costs.

${ }^{3}$ Donaldson was the first to suggest the Pecking Order Theory in 1961.
} 
bankruptcy costs and the value of tax shields allow the firm to optimize its overall value by focusing on this trade-off when choosing debt and equity for its financing. Hence, the financial structure is explained by the search for an optimal debt ratio that reflects the tradeoff between the tax savings from debt and of a possible bankruptcy costs (Baxter 1967, Stiglitz 1969), on one hand, or one that results from a tradeoff between the equity and debt agency costs (Jensen and Meckling 1976), on the other hand.

The second, following Myers (1984), states that " a firm is said to follow a pecking order if it prefers internal to external financing and debt to equity if external financing is used". Due to information asymmetries between internal and external financing and between the issue of debt or equity, this theory follows a funding hierarchy. It does not propose any optimal debt ratio definition (Myers 1984, Myers and Majluf 1984) and have not been able to show what it is of firstorder importance in determining a firm's capital structure (Fama and French 2002, Myers and Shyam-Sunder 2002).

The third theory states that firms prefer external equity when the cost of equity is low, and prefer debt otherwise. Conditional on having financing needs, the market timing theory refers to the practice of issuing shares at high prices and repurchasing at low prices. Unlike the first two theories, it states that the choice of financing methods depends on market conditions. Firms must increase their capital if the stock market climate is favorable and go into debt or redeem their securities in the opposite case (Baker and Wurgler 2002, Hovakimian 2004).

All these theories assume, implicitly, the homogeneity of firms and the dichotomy between the real and financial sectors, leading to a diversity of empirical results that are often contradictory. Indeed, in some cases the factors resulting from the Tradeoff Theory are advanced as the main determinants of a financial structure, whereas in others it is the predictions of the Pecking Order or the Market Timing Theories that are empirically validated. It follows from these facts that these theories provide only partial explanations for the financing policy of firms.

In order to enrich the developments of such approaches, the purpose of our paper is to show the diversity of behaviors financing using the convention theory ${ }^{4}$.This approach has the advantage of bridging the funding theories gaps in the explanation of funding decisions. It takes also into account the heterogeneity of firms, the uncertainty, the incompleteness of agents' behavior and the real characteristics of firms.

The convention approach is based on two fundamental assumptions (Paranque et al. 1999):

\footnotetext{
${ }^{4}$ “'Convention theory was birthed in France, parented by late-70s economics and sociology theory before being adopted into management theory in the 1990s". "The new label for this approach soon became 'convention theory' or the economics of conventions (in French 'économie des conventions') - hence its abbreviation ' $\mathrm{EC}$ '. The core assumption of $\mathrm{EC}$ is that economic value and worth have to be interpreted and constructed according to situations of economic coordination. Economic actors therefore rely on conventions as socio-cultural frames for mobilizing a shared interpretation of the objects, actions, goals, and collective intentions involved in situations of production, distribution, and consumption" (Rainer Diaz-Bone 2016).
} 
- The incompleteness of the contracts according to Herbert Simon(1976);

- The decisions as well as the anticipations of the agents are taken in an uncertain world following (Knight (1921)) and Rivaud-Danset (1992, 1998).

Based on these assumptions, the convention theory asserts that the financial structure of a firm results from the nature of its financing needs and its financial performance, on the one hand, and from its ability to obtain resources from banks. These two factors depend on the actual characteristics of the firm and the nature of its relationship with the banks. Thus, the convention theory offers an explanation for divergences in the financing behavior of firms of the same size and of the same sector of activity. It admits, contrary to the theories presented above, the heterogeneity of financing structures and argues that several financing schemes may be suitable for firms. These plans correspond to agreements that reflect the management of financial flexibility and that are likely to be suitable for the various players financing the firm.

To this end, three financing schemes can be identified: the autonomy regime, based on self-financing of the firm's activities; the debt regime, based on debt financing; and the overdraft regime, which is based on capital financings and bank overdrafts (Myers and Majluf 1984, Hicks 1975).This plurality of financing regimes shows the existence of several financial structures that may be suitable for firms (Rivaud-Danset and Salais 1993).

The convention theory states that the financial structure reflects the way of managing the flexibility that flows from the world of production ${ }^{5}$. Thus, firms in the world of industrial production ${ }^{6}$ choose to borrow to fill their financing gap while firms in the world of interpersonal ${ }^{7}$ and commercial production ${ }^{8}$ resort to bank overdraft to finance needs related to unforeseen hazards. Firms in the world of intangible production ${ }^{9}$ use their own resources to maintain their flexibilities. The distinction between the overdraft option and the autonomy option goes back to Hicks (1975) who pointed out the impact of liquidity on investment in uncertain situations. Indeed, the financing of the investment does not depend solely on the interest rate as shown by Keynes (1936), but also on the liquidity of the firms that

\footnotetext{
${ }^{5}$ The world of production corresponds to space of coordination between producers and consumers. It includes all the institutional arrangements associated with them (Cazals and Bergouignan 2009, Salais and Storper 1993) were the first to introduce the concept to highlight the heterogeneity of firms and the coordination uncertainties surrounding the product.

${ }^{6}$ The industrial world is characterized by mass production for large markets and composed of anonymous demanders. The products are standardized and the wage is based on an objective description of the work. The demand is predictable, technologies are known and the economic risk is quantifiable.

${ }^{7}$ The interpersonal world concerns dedicated products according to a specialized process. It is characterized by the singularity of the people and the customers and by the individualization of the productions. In this case, relationships between actors are usually based on trust.

${ }^{8}$ The merchant world is that of products manufactured according to the standardization convention, but dedicated to a particular demander. Competition between firms is generally about price and delivery times.

${ }^{9}$ The intangible world is characterized by the creation of technologies and the design of new product families. Firms invest primarily in basic research and face uncertainty about the future.
} 
allow the financing of the need for financial flexibility (internal or external). The firm's internal liquidity is ensured by the holding of easily tradable assets, while external liquidity comes from the ability to use bank loans. This debt capacity is like an invisible asset and can only be considered in the context of a customer relationship between the firm and its bank. As a result, the manner of appropriating liquidity determines the method of financing the firm.

The first empirical studies, based on a sample of French firms (Paranque and Rivaud-Danset 1998) showed the existence of three financing regimes. They have shown that the autonomy regime is not necessarily associated with greater economic dynamism or high performance of firms, and argue that the debt regime is correlated with high investment rate and high level of financial profitability, and that the sustainability of some firms is conditional on high liquidity.

By adopting a similar methodology, Trabelsi (2006) examined the financing choices of small and medium-sized firms; she showed that different financing regimes exist within the same sector and that the nature of the activity and a degree of uncertainty determine the structure of firms' assets and their management of financial flexibility, respectively.

In our work, concentrating upon the Morocco case, we check for the existence of these financing regimes or agreements based on a panel of listed Moroccan firms of Casablanca stock exchange. The paper is organized as follows. Section 2 describes the financing decisions of Moroccan companies. Section 3 explains the methodology and sets up the notation. Section 4 implement the method to analyze by PCA and HCA the covariance structure of the funding regimes and report our findings. The last section concludes.

\section{Financing Decisions of Moroccan Firms Listed on the Casablanca Stock Exchange}

Internal Equity Financing

Internal equity financing is a type of financing favored by the Moroccan firms. Our finding, according to the survey we conducted in 2011 , is that over $71 \%$ of financing sources come from internal funding (Bouayad and al. 2012). The other surveys conducted by ICA (2004) and FACS (2000) were found the same results, $62 \%$ and $63 \%$ respectively. This behavior can be justified by several factors, including the reluctance of Moroccan firms to access external financing methods, the negative of manager's attitude vis-à-vis the debt, the asymmetry of information that characterizes the Moroccan financial market and the low investment of industrial companies which leads to a limited demand for financial resources in the long term.

\section{Financing by Capital Increase}

The use of capital increases by Moroccan firms is infrequent. The firm's desire for discretion and independence may justify the lack of recourse to capital 
increases. Indeed, firms are obliged to disclose their accounting and financial information when they decide to issue securities. This market requirement provides competitors with valuable information and can contribute to the vulnerability of the issuing firms.

Table 1. Evolution of Capital Increases by Issuer Type (In MAD Millions)

\begin{tabular}{|c|c|c|c|c|}
\hline \multirow{2}{*}{ Years } & \multirow{2}{*}{$\begin{array}{c}\text { Initial Public Offering } \\
\text { (IPO) }\end{array}$} & \multicolumn{2}{|c|}{ Other } & \multirow{2}{*}{ Total } \\
\cline { 3 - 4 } & ---- & $\begin{array}{c}\text { Non-financial } \\
\text { firms }\end{array}$ & $\begin{array}{c}\text { Financial } \\
\text { firms }\end{array}$ & \\
\hline 2003 & ---- & ---- & 251.04 & 251.04 \\
\hline 2004 & 29.5 & ---- & 5820.5 & 5820.5 \\
\hline 2005 & 479.7 & 1147.7 & 1850.0 & 3027.2 \\
\hline 2006 & 2421.3 & 28.63 & ---- & 508.33 \\
\hline 2007 & 1718.35 & 2337.48 & ---- & 4758.87 \\
\hline 2008 & ---- & ---- & 3008.37 & 4726.72 \\
\hline 2009 & ---- & ---- & 1002.18 & 1002.18 \\
\hline 2010 & $\mathbf{4 6 4 8 . 9 4}$ & 2992.5 & 3017.32 & 6009.82 \\
\hline Total & $\mathbf{6 5 0 6 . 3 1}$ & $\mathbf{1 4 9 4 9 . 4}$ & $\mathbf{2 6 1 0 4 . 6 6}$ \\
\hline
\end{tabular}

Source: Different Bank-Al-Maghrib reports and Moroccan Capital Markets Authority reports.

The main issuers of shares on the primary market are financial institutions. Over the period 2003-2010, as we see in table 1, they issued 15 MAD billion (more than $57 \%$ of total volume issued by Moroccan companies). The capital increases in cash resulting from IPOs represent less than $18 \%$ of total volume issued on the primary market. Similarly, the capital increases carried out by listed non-financial corporations do not exceed 6.5 MAD billion over the period 20032010. This confirms that the shareholding culture is very little developed in Morocco.

Capital increases by contribution in kind are mainly made following mergersacquisitions, with 7.2 MAD billion over the period 2003-2010. Four capital increase operations by dividend conversion, totaling 1.3 MAD billion, were carried out over the same period by financial institutions.

\section{Bank Loan Financing}

Given the economic importance of bank loan financing in business financing, the share of bank debt in total indebtedness of Moroccan private non-financial firms exceeds $96 \%$ over the period 2003-2010. 94\% of contracted loans by listed firms over the period 2003-2010 come from banking sector. For the non-financial firms publicly listed in the Casablanca Stock Exchange (CSE), table 2 presents the evolution of their bank debts. 
Table 2. Evolution of Bank Debt of Non-Financial Firms Publicly Listed in CSE (in MAD Millions)

\begin{tabular}{|l|c|c|c|c|}
\hline Years & Bank debts & \% change & Total debt & Weight \\
\hline 2003 & 4439.5 & --- & 4439.35 & 1 \\
\hline 2004 & 6325.09 & 42.48 & 6325.09 & 1 \\
\hline 2005 & 9496.77 & 50.14 & 9946.77 & 0.95 \\
\hline 2006 & 15011.57 & 58.07 & 15011.57 & 1 \\
\hline 2007 & 24266.44 & 61.65 & 24336.44 & 0.997 \\
\hline 2008 & 27255.8 & 12.32 & 29555.8 & 0.92 \\
\hline 2009 & 32815.94 & 20.4 & 3307.94 & 0.99 \\
\hline 2010 & 31931.348 & -2.69 & 39177.57 & 0.81 \\
\hline Total & $\mathbf{1 5 2 1 5 1 . 7 1 8}$ & --- & $\mathbf{1 6 1 8 6 3 . 5 3}$ & $\mathbf{0 . 9 4}$ \\
\hline
\end{tabular}

Source: Bank Al-Maghrib reports (2003-2010).

From table 2, the loans granted to listed firms have steadily increased each year, from 4.4 MAD billion in 2003 to 31.9 billion in 2010, showing that these companies prefer bank credit, in case of recourse to external financing. In addition, the period 2003-2007 was marked by a high growth in bank loans, which peaked in $2007(+61.65 \%)$.

This trend can be, partly, explained by the easing of credit conditions due to the excess liquidity of the banking system. Under these conditions, conventional banks have become more competitive than other financial intermediaries. However, since 2008, the international financial crisis has had a negative impact on the liquidity of banks, (lower foreign exchange inflow related to tourism receipts and transfers of Moroccans living abroad) forcing them to turn to Bank Al-Maghrib to refinance leading to an upward trend in bank lending rates which affected the share of bank loans in total indebtedness of non-financial companies listed on the stock market, from $100 \%$ in 2003 to $81 \%$ in 2010

\section{Bond Financing}

Bond financing have a clear advantage over other securities and are generally viewed as safer investments than stocks. In tables 3 and 4, we present the evolution of bond issues of Moroccan firms, their distribution by issuer category and their weight by stock market compartment.

Table 3. Evolution of Bond Issues of Moroccan Firms Listed on the CSE (In Millions of Dh)

\begin{tabular}{|l|c|c|}
\hline Years & Amount issued & Rate of growth \\
\hline 2003 & 4352 & --- \\
\hline 2004 & 5602 & 28.72 \\
\hline 2005 & 3195 & -42.97 \\
\hline 2006 & 4130 & 29.26 \\
\hline 2007 & 5065 & 22.64 \\
\hline 2008 & 13300 & 162.59 \\
\hline 2009 & 13100 & -1.5 \\
\hline 2010 & 25636 & 95.7 \\
\hline
\end{tabular}

Source: Bank Al-Maghrib reports (2003 - 2010). 
The bond issues by the firms could not exceed 10 MAD billion per year over the period 2003 - 2007 for several reasons: (i) the ease access to bank credit; (ii) the sufficient cash flow generated by the issuing firms over the period 2003-2007. Indeed, the financial companies that were the main issuers of bonds over this period recorded exceptional results due to the strong credit expansion. However, after 2007, these same companies had a massive recourse to bonds that exceeded 25 MAD billion in 2010 due to a lack of liquidity on the interbank market because of the international financial crisis. Thus, the growing interest of companies for bond issues over the period 2008-2010 is consistent with the predictions of Market Timing theory which states that firms resort more to bond issues when the stock markets are declining. Table 4 shows the breakdown of bonds issued by nonfinancial corporations by issuer category.

Table 4. Bond Issues of Listed Non-Financial Corporations by Issuer Category

\begin{tabular}{|l|c|c|c|c|}
\hline Years & Holdings & Other & Weight & Total \\
\hline 2003 & 0 & 0 & 0 & 0 \\
\hline 2004 & 1200 & 0 & 0 & 1200 \\
\hline 2005 & 0 & 450 & 1 & 450 \\
\hline 2006 & 2500 & 0 & 0 & 2500 \\
\hline 2007 & 1200 & 70 & 0.05 & 1270 \\
\hline 2008 & 2200 & 3800 & 0.63 & 6000 \\
\hline 2009 & 1500 & 1750 & 0.54 & 3250 \\
\hline 2010 & 6300 & 7546.22 & 0.54 & 13846.22 \\
\hline Total & $\mathbf{1 4 9 0 0}$ & $\mathbf{1 3 6 1 6 . 2 2}$ & $\mathbf{0 . 4 7}$ & $\mathbf{2 8 5 1 6 . 2 2}$ \\
\hline
\end{tabular}

Source: Bank Al-Maghrib reports and the balance sheets of Moroccan non-financial listed companies.

We note that over the period 2003-2010, the bond issues of listed holding companies, notably ONA and SNI, represent more than half of the total amount issued $(52.52 \%)$. Nevertheless, over 2008-2010, the share of firms other than holding companies was higher than $50 \%$ and reached $63 \%$ in 2008 . This renewed interest in private debt can be explained, on the firm side, by the tightening of credit conditions, which mainly affected large companies, and on the investor side, by lowering bank credit rates and lower Treasure bond rates. It should also be noted that unlisted non-financial firms, as well as unlisted holdings, also issued bonds in the private debt market amounting to MAD 6.74 billion over the period 2003-2010, i.e. $24 \%$ of total issues on the Moroccan bond market.

\section{Methodology}

Drawing on prior works (Paranque and Rivaud-Danset 1998, Trabelsi 2006), we try to determine the existing financing regimes in Morocco by using, first, a Principal Component Analysis (PCA) to determine a more appropriates factors that determine the choice of such regimes. We then proceed, second, to a hierarchical cluster analysis (HCA) to group firms by funding regime to obtain information on the weight and characteristics of each regime. 
Our study covers all Moroccan non-financial firms listed on the three trading compartments of Casablanca Stock Exchange (CSE), namely principal, development and growth markets (table 5). We use a panel of listed 50 nonfinancial firms ${ }^{10}$ of CSE over the period 2003-2010. We didn't use any sampling criteria and condition on the activity sector and size due to the limited number of non-financial firms listed on the CSE. The data relating to fiscal years prior to 2003 were not available for several non-financial firms. Thus, to have a cylinder panel, we have chosen only companies for which we have at least 8 accounting years.

Table 5. Number of Firms by Trading Compartment

\begin{tabular}{|l|c|c|}
\hline Compartment & Number & Frequency \\
\hline Principal & 29 & 0.58 \\
\hline Development & 13 & 0.26 \\
\hline Growth & 8 & 0.16 \\
\hline Total & 50 & 1 \\
\hline
\end{tabular}

Source: Our compilation.

The firms selected are still listed in $2018^{11}$ and adopt, over the 2011-2017 period, a similar financing behavior to that of the period $2003-2010$. From 2011 to 2017 , non-financial listed firms still used internal capital to cover $80 \%$ of their financing needs (79\% for the period 2003-2010)

\section{Hypothesis and Selected Variables}

Conventions theory states that several financing schemes may be suitable for firms and the choice of a financing regime is influenced by the nature of the need to be financed. The purpose of this work is twofold: (i) to check the existence of these schemes or financing agreements on a panel of Moroccan companies listed on the Casablanca Stock Exchange and, (ii) to see if the choice of a financing regime affects the economic performance and financial position of the firm. From these two objectives flow the two hypotheses of our empirical study:

H1: Firms adhere to funding schemes according to the need to be financed;

$\mathrm{H} 2$ : Economic and financial performance differs from one funding regime to another.

The variables selected represent the different financing alternatives offered to firms. Thus, financial autonomy reflects the autonomy regime based on selffinancing of the firm's activities. Medium and long-term indebtedness provides information on the debt regime of firms who adopt a financing policy based mainly on medium- and long-term debt. The bank overdraft reflects the overdraft regime to which short-term borrowing firms subscribe for financing their

\footnotetext{
${ }^{10} 56$ Moroccan non-financial firms are listed on the CSE on November $29^{\text {th }}, 2012$.

${ }^{11}$ In July 2018, 58 non-financial firms are listed on the Casablanca Stock Exchange
} 
operating needs.

We introduced variables that (i) represent the nature of needs to be financed to determine funding regimes and that (ii) provide information on firm's economic and financial profitability. Table 6 below summarizes the measurement and definition of variables used in our study.

Table 6. Definition and Variable Measurement

\begin{tabular}{|c|c|c|}
\hline Variable & Definition & Measurement \\
\hline Aut & Financial autonomy & Equity/Total assets \\
\hline End & $\begin{array}{l}\text { Medium and long } \\
\text { term debt }\end{array}$ & Long and medium liabilities /Total assets \\
\hline Dec & Bank overdrafts & Short term liabilities/Total assets \\
\hline Bfi & $\begin{array}{l}\text { Investment } \\
\text { financing need }\end{array}$ & Tangible assets/Total assets \\
\hline Bft & $\begin{array}{c}\text { Transactions } \\
\text { funding requirement }\end{array}$ & Current assets (without cash)/Total assets \\
\hline Bfs & $\begin{array}{l}\text { Specific asset } \\
\text { financing need }\end{array}$ & Intangible assets/Total assets \\
\hline Bfr & $\begin{array}{l}\text { Working capital } \\
\text { need }\end{array}$ & $\begin{array}{c}\text { Current assets (without cash)- Current liabilities } \\
\text { (without bank overdraft))/Total assets }\end{array}$ \\
\hline Rec & $\begin{array}{l}\text { Economic } \\
\text { profitability }\end{array}$ & $\begin{array}{c}\text { Gross operating surplus/ (non-current assets + } \\
\text { Current assets (without cash) - Current } \\
\text { liabilities (without bank overdraft)) }\end{array}$ \\
\hline Rfi & $\begin{array}{l}\text { Financial } \\
\text { profitability }\end{array}$ & Net income/ Equity \\
\hline
\end{tabular}

Source:Author.

\section{Empirical Results}

In our study, the attempt is made to determine the financing regime in regard to selected variables. Before presenting the PCA and HCA statement of the results we begin with a descriptive statistical analysis of the variables.

Table 7. Description of the Variables

\begin{tabular}{|c|c|c|c|c|c|}
\hline Variable & Mean & $\begin{array}{c}\text { Standard } \\
\text { deviation }\end{array}$ & $\begin{array}{c}\text { Coefficient of } \\
\text { variation }\end{array}$ & Minimum & Maximum \\
\hline Aut & 0.479 & 0.207 & 2.310 & 0.005 & 0.946 \\
\hline End & 0.077 & 0.114 & 0.674 & 0 & 0.622 \\
\hline Dec & 0.107 & 0.123 & 0.866 & 0 & 0.659 \\
\hline Rfi & 0.068 & 1.255 & 0.054 & -22.901 & 0.608 \\
\hline Rec & 0.207 & 0.235 & 0.881 & -1.432 & 2.585 \\
\hline Bfr & 0.291 & 0.209 & 1.392 & -0.265 & 0.804 \\
\hline Bfi & 0.242 & 0.200 & 1.213 & 0 & 0.848 \\
\hline Bfs & 0.024 & 0.065 & 0.371 & 0 & 0.772 \\
\hline Bft & 0.578 & 0.224 & 2.575 & 0.020 & 0.970 \\
\hline
\end{tabular}

Source:Author.

The result, as shown from table 7, suggest the existence of higher dispersion of "financial autonomy" variable than others, showing a greater volatility 
throughout the period and heterogeneity of the firms' behavior who do not obey to standards in their mobilization of funds. This finding suggests that this dispersion is not due to its inter-firms but intra-firms variability.

The existence of standards for bank overdrafts and long-term debt for the other two variables of the financing regime might be justified by the values of their coefficients of variation which are less than 1 . For the others, short term financing needs over 2003 to 2010 is desired, especially after the 2007 financial crisis. Consequently, we can confirm, on the basis of the values of coefficients of variation of the firm's economic and financial profitability, the existence of norms, unlike those of Bfr and Bfi variables which show an heterogeneity of the behavior of firms if we trust the coefficients of variation which are higher than 1.

Using PCA, the results (table 8) show that the first four components explain about $75 \%$ of the total variance of selected variables ${ }^{12}$.

Table 8. Total Variance Explained

\begin{tabular}{|l|c|c|c|}
\hline Component & IE $^{*}$ & PVE $^{* *}$ & PCVE $^{* * *}$ \\
\hline 1 & 2.674 & 29.707 & 29.707 \\
\hline 2 & 1.880 & 20.885 & 50.592 \\
\hline 3 & 1.168 & 12.975 & 63.567 \\
\hline 4 & 1.007 & 11.190 & 74.758 \\
\hline 5 & 0.880 & 9.774 & 84.532 \\
\hline 6 & 0.590 & 6.561 & 91.092 \\
\hline 7 & 0.514 & 5.708 & 96.800 \\
\hline 8 & 0.237 & 2.628 & 99.428 \\
\hline 9 & 0.051 & 0.572 & 100 \\
\hline
\end{tabular}

*Initial eigenvalues; $* *$ Proportion of variance explained; ***Proportion of cumulative variance explained

Source: Author.

We note that the initial eigenvalues of the first four components are greater than the mean of the initial eigenvalues. Those of the other five components are lower than this mean. They explain only a very small part of the total variance. Table 9 shows the contribution of the quality of the representation of each variable.

Table 9. Quality of Representation

\begin{tabular}{|l|c|c|c|c|c|c|c|c|c|}
\hline Variables & Aut & End & Dec & Rfi & Rec & Bfr & Bfi & Bfs & Bft \\
\hline Extraction & 0.940 & 0.681 & 0.651 & 0.370 & 0.788 & 0.831 & 0.762 & 0.839 & 0.867 \\
\hline
\end{tabular}

Source:Author.

The global quality of the empirical results for three variables reflecting financing regimes seems widely satisfactory since more than $65 \%$ of their variance has been taken into account by one of the dimensions extracted by CPA. Moreover, financial autonomy has an explained variance greater than $90 \%$. Similarly, the variances exceed $75 \%$ for variables reflecting the nature of needs to

\footnotetext{
${ }^{12} \mathrm{We}$ limited the presentation to the first four components because the others have initial eigenvalues less than one. Thus, they explain only a very small part of total variance.
} 
be financed. In addition, financial profitability is the least taken into account by four dimensions extracted.

Our results show the existence of distinct funding regimes influenced by nature of funding needs ${ }^{13}$. However, confirmation of these results should also be sought in reviewing details of variables on different axes. To do so, we analyze the matrix of components (table 10) that corresponds to extracted dimensions and presents correlation coefficients of variables.

Table 10. Components Matrix

\begin{tabular}{|l|c|c|c|c|}
\hline \multirow{2}{*}{ Variable } & \multicolumn{4}{|c|}{ Component } \\
\cline { 2 - 5 } & $\mathbf{1}$ & $\mathbf{2}$ & $\mathbf{3}$ & $\mathbf{4}$ \\
\hline Aut & 0.043 & 0.960 & 0.027 & 0.125 \\
\hline End & -0.594 & -0.428 & -0.365 & 0.108 \\
\hline Dec & 0.383 & -0.621 & -0.288 & 0.188 \\
\hline Rfi & 0.095 & 0.212 & 0.541 & -0.150 \\
\hline Rec & -0.097 & -0.034 & 0.857 & 0.208 \\
\hline Bfr & 0.827 & 0.107 & -0.181 & 0.321 \\
\hline Bfi & -0.809 & 0.089 & -0.003 & 0.315 \\
\hline Bfs & -0.062 & -0.005 & -0.033 & -0.913 \\
\hline Bft & 0.875 & -0.248 & 0.084 & 0.180 \\
\hline
\end{tabular}

From figure 1, the most correlated variables with first axis are working capital requirement (Bfr), the financing requirement for capital assets (Bfi) and transactions financing needs $(\mathrm{Bft})$. This shows that the first component represents the nature of need to be financed. The second component represents the nature of financing since the most correlated variables with the second axis are financial autonomy (Aut), long and medium terms indebtedness (End) and bank overdrafts (Dec).

Figure 1. Diagram of Components 1 and 2

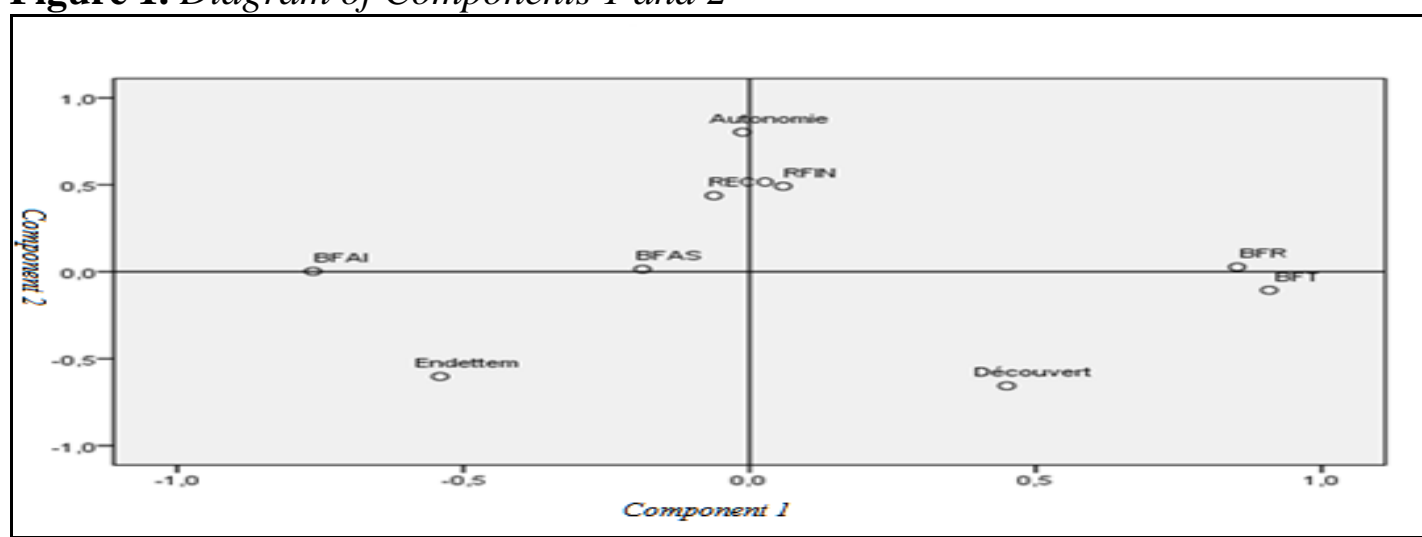

Component 1: Nature of the funding requirement

Component 2: Nature of funding (Equity/Financial debts)

Source: Author.

\footnotetext{
${ }^{13}$ The three representative variables of funding agreements are well represented by four dimensions extracted.
} 
In two first axes, financial autonomy variable is opposed to debt variables $((E n d)$ and $(D e c))$ suggesting the existence of three funding regimes, namely autonomy, debt and overdraft. To refine our finding, we present in table 11 coordinates variables in descending order for the first three components that account for over $65 \%$ of total variance.

Table 11. Coordinates Variables on the Components

\begin{tabular}{|l|c|c|c|c|c|c|c|c|c|}
\hline Variable & Bft & Bfr & Dec & Rfi & Aut & Bfs & Rec & End & Bfi \\
\hline Component1 & 0.875 & 0.827 & 0.383 & 0.095 & 0.043 & -0.062 & -0.097 & -0.594 & -0.809 \\
\hline Component2 & 0.960 & 0.212 & 0.107 & 0.089 & -0.005 & -0.034 & -0.248 & -0.428 & -0.621 \\
\hline Component3 & 0.857 & 0.541 & 0.084 & 0.027 & -0.003 & 0.033 & -0.181 & -0.288 & -0.365 \\
\hline
\end{tabular}

Source:Author.

The first component shows a clear opposition between funding needs. Indeed, we observe a negative correlation between transactions financing needs (Bft) and financing requirement for capital assets (Bfi) due to the existence of two types of firms: those with an investment financing needs and those with transactions financing needs. Thus, we observe a positive correlation between (Bfi) and debt, showing that tangibility of assets is an important factor that explains financial structure of firms. Similarly, firms' working capital requirement arises from transactions financing needs and not from investment financing needs (Bfr is correlated positively with the Bft and negatively with the Bfi).

Component 2 shows distinction between two funding regimes: autonomy and overdraft. We observe a positive correlation between self-financing and economic and financial profitability, and a weak correlation between financing need of a specific asset and component 2, leading to the fact that listed Moroccan firms of stock exchange invest little in research and development and explain a weak correlation between financing regimes and the specificity of the asset.

According to component 3, variables related to firm's economic and financial performance are highly significant with a correlation coefficient for the economic return (Rec) equal to $85.7 \%$, and $54.1 \%$ for the case of profitability (Rfi).We note that (Rec) and (Rfi) differ from debt and overdraft regimes but consistent with autonomy convention, confirming the finding of the Pecking order theory which states that less profitable firms are the most indebted. We also note that (Rec) and (Rfi) differ from the debt and overdraft regimes but in consistent with the autonomy convention, confirming the finding of the Pecking order theory.

Although the results show the existence of three funding regimes characterized by nature of financing needs and firm's economic and financial profitability, the CPA does not characterize accurately financing agreements. To overcome this shortcoming, we will adopt the HCA by grouping firms having same characteristics to obtain information on the weight of each funding regime based on number of firms per cluster. This will allow us to describing them also by variables. 
Table 12. Distribution of Firms by Cluster

\begin{tabular}{|l|c|c|c|c|c|}
\hline Cluster & $\mathbf{1}$ & $\mathbf{2}$ & $\mathbf{3}$ & $\mathbf{4}$ & Total \\
\hline Headcount & 25 & 12 & 10 & 3 & 50 \\
\hline
\end{tabular}

Source:Author.

According to three regimes, we form four clusters which consist of 50 firms. Considering the sizes, one larger cluster, two intermediate and the smaller one, have been separated. From Table 12, the first cluster contains 50\% of companies (25), the second, 12 firms (24\%), the third, with 10 companies represents $20 \%$ of the sample while the fourth represents only $6 \%$ with 3 firms. Table 13 presents the characteristics of each cluster.

Table 13. Description of Firms and Four Clusters

\begin{tabular}{|l|c|c|c|c|c|}
\hline Variable & Cluster 1 & Cluster 2 & Cluster 3 & Cluster 4 & Mean \\
\hline Aut & 0.641 & 0.334 & 0.315 & 0.403 & 0.423 \\
\hline End & 0.035 & 0.183 & 0.021 & 0.072 & 0.078 \\
\hline Déc & 0.046 & 0.141 & 0.230 & 0.040 & 0.114 \\
\hline Rfi & 0.167 & -0.166 & 0.174 & 0.081 & 0.064 \\
\hline Rec & 0.208 & 0.214 & 0.240 & 0.070 & 0.183 \\
\hline Bfr & 0.318 & 0.191 & 0.435 & 0.111 & 0.264 \\
\hline Bfi & 0.260 & 0.358 & 0.062 & 0.110 & 0.197 \\
\hline Bfs & 0.015 & 0.008 & 0.005 & 0.231 & 0.065 \\
\hline Bft & 0.541 & 0.484 & 0.855 & 0.460 & 0.585 \\
\hline
\end{tabular}

Source:Author.

There are 25 firms in the first cluster with highest self-financing rate (64\%), lowest debt ratio (long-term debt: $3.5 \%$, short-term debt: $4.6 \%$ of total assets) and more financial profitability than average but lower economic returns than the other two. At the examination of this first cluster, we made a conclusion that a majority of firms, $50 \%$, adhere to the autonomy regime.

The second cluster contains $24 \%$ of firms that are more indebted (highest medium and long-term debt ratio, $18.3 \%)$, investing more $(\mathrm{Bfi}=35.8 \%)$ but with a negative financial rate of return $(-16,6 \%)^{14}$. This second cluster of firms adheres to debt regime.

The third cluster represent $20 \%$ of firms that have a highest short-term debt ratio $(23 \%)$ resulting from high transactions financing needs $(85.5 \%)$ and showing that the most of the working capital requirement arises from current transactions. Firms of this cluster invest least $(\mathrm{Bfi}=6.2 \%)$ but with a high financial profitability (17.4\%). This cluster is associated to Hicks' (1975) overdraft regime.

The fourth cluster, which includes only three firms, cannot be associated with any regime because all their variables have lower values than the average.

\footnotetext{
${ }^{14}$ Our results are consistent with those obtained by Myers and Majluf (1984) who argue that debt is associated with low financial profitability.
} 


\section{Conclusion}

Our analysis investigated the classification of firms by financing regimes. These schemes depended on nature of needs to be financed which, in turn, depended on the actual firm characteristics.

Based on the ACP and HCA, we have attempt to show the existence of three funding regimes characterized by nature of financing needs and firm's economic and financial profitability. The CPA does not characterize accurately financing agreements. We adopt the HCA analysis to overcome this shortcoming, and obtain information on the weight of each funding regime per cluster.

We notice as a conclusion for the study made for the listed Moroccan firms over the period 2003 - 2010, the existence of three distinct funding regimes: (i) the autonomy regime that has the feature to have a good financial performance; (ii) the debt regime that gives the importance to investments and (iii) the overdraft regime that places the importance on financing needs of transactions.

The results have important implications on the study of the determinants of financing decisions, because observed heterogeneity of the financing behaviors necessitated taking into account the nature of the financing needs into the study of a firms' financial structure. However, the generalization of the results to all Moroccan companies requires the analysis of the financial behavior of companies that are not listed, especially SMEs which represent $95 \%$ of the national economic structure. Furthermore, the regularity of financing behavior requires further research on factors, other than the nature of financing needs that lead firms to adhere to such regime. We believe that a qualitative approach based on interviews with business leaders will help to better understand these factors. We hope to pursue these extensions in future work.

\section{References}

Baker M, Wurgler J (2002) Market timing and capital structure. Journal of Finance 57: 132.

ICA (2004) Banque Mondiale et Ministère de l'Industrie, du Commerce et la Mise à niveau de l'économie [World Bank and Ministry of Industry, Trade and Economic Upgrading] (2005). Evaluation du climat des affaires au Maroc.

Baxter N (1967) Leverage, risk of ruin and the cost of capital. Journal of finance 22: 395403.

Bouayad B (2012) L'évaluation du processus de réformes et mise à niveau efficiente des entreprises dans le cadre d'un développement durable: cas des entreprises marocaines à l'horizon 2010, Rapport de recherche financé par TrustAfrica[Evaluation of the reform process and efficient upgrading of enterprises in the context of sustainable development: the case of Moroccan companies by 2010, Research report financed by TrustAfrica]. Laboratoire de Recherche en Economie de l'Energie, Environnement et Ressources, Université Cadi Ayyad, Marrakech.

Cazals C, Bergouignan M C (2009) Mondes de production et protection de l'environnement dans deux filières Agricoles [Production worlds and protection of the environment in two agricultural sectors]. Économie rurale: 313-314.

Donaldson G (1961) Corporate debt capacity: A study of corporate debt policy and the 
determination of corporate debt capacity. Boston, division of Research, Harvard Graduate School of Business Administration.

Fama E, French K (2002) Testing Tradeoff and Pecking Order predictions about dividends and debt. Review of Financial Studies (15): 1-37.

Frank Murray Z, Goyal Vidhan K (2011) Trade-off and Pecking Order Theories of Debt. Handbook of Empirical Corporate Finance: Empirical Corporate Finance. Elsevier: 135-202.

Hicks J (1975) The Crisis in Keynesian Economics. Basic Blackwell, Oxford.

Hovakimian A (2004) The role of target leverage in security issues and repurchases. Journal of Business 77 (4): 1041-1072.

Jensen M, Meckling WH (1976) Theory of the firm: managerial behavior, agency costs and ownership structure. Journal of Financial Economics (3): 305-360.

Keynes JM (1936) The General Theory of Employment, Interest and Money. Mac Millan, Cambridge University Press.

Knight FH (1921) Risk, uncertainty and profit. New-York, Hougton Mifflin.

Kraus A, Litzenberger RH (1973) A State-Preference Model of optimal financial leverage. Journal of Finance: $911-922$.

Modigliani F, Merton HM (1958) The Cost of Capital, Corporation Finance and the Theory of Investment, The American Economic Review, 48: 261-297.

Myers SC (1984) The capital structure puzzle. Journal of Finance 39(3): 575-592.

Myers SC, Majluf NS (1984) Corporate financing and investment decisions when firms have information that investors do not have. Journal of Financial Economics 13: 187-221.

Myers and Shyam-Sunder (2002) Testing Trade-Off and Pecking Order Predictions about dividends and debt. Review of Financial Studies.

Paranque B, Friderichs H, Gerdesmeier D, Kremp E, Kremp A, Scheuer M, Stöss E (1999) Modes de financement des entreprises allemandes et françaises. Projet de recherche commun de la Deutsche Bundesbank et de la Banque de France.

Paranque B, Rivaud-Danset D (1998) Structure Financière des entreprises industrielles françaises: une approche en termes de conventions de financement. Bulletin de la Banque de France, Numéro 57, Septembre.

Rainer Diaz-Bone (2016) Convention theory and neoliberalism. Journal of Cultural Economy 9(2): 214-220. DOI: 10.1080/17530350.2015.1083879.

Rivaud-Danset D (1998) Le traitement de l'incertitude en situation : Une lecture de Knight, In Institutions et conventions : la réflexivité de l'action économique Editions de l'Ecole des Hautes Etudes en Sciences Sociales, Paris.

Rivaud-Danset D, Salais R (1992) Les conventions de financement. Premières approches théorique et empirique. Revue Française d'Économie 7 (4).

Salais R, Michael Storper (1993) Les mondes de production. Enquête sur Videntite economique de la France. Editions de l'Ecole des Hautes Etudes en Sciences Sociales, Paris, 467.

Simon H (1976) From substantive to procedural rationality. Cambridge University Press, $129-148$.

Stewart CM, Majluf N (1984) Corporate financing and investment decisions when firms have information that investors do not have. Journal of Financial Economics, 1984

Stiglitz J (1969) A Re-Examination of the Modigliani-Miller theorem. American Economic Review, 59(5): 784-793.

Trabelsi A (2006) Les Déterminants de la Structure du Capital et les Particularités du Financement dans les PME: une Etude sur Données Françaises. Thèse de doctorat en Sciences de Gestion, Université Paris IV Dauphine. 
World Bank (2000) Moroccan manufacturing sector at the turn of the century: Results of the firm analysis and competitiveness survey (FACS-MOROCCO 2000). 